\title{
IMPLEMENTASI UUD NKRI 1945 PASAL 31 AYAT 1 MELALUI PENGENTASAN BUTA AKSARA PROGRAM NASIONAL PEMBERDAYAAN MASYARAKAT GENERASI SEHAT DAN CERDAS (PNPM-GSC) TERHADAP PENINGKATAN KESADARAN PENDIDIKAN MASYARAKAT DIDESA TAWANG SARI KECAMATAN SEPAUK KABUPATEN SINTANG
}

\author{
Suparno, Geri Alfikar \\ STKIP Persada Khatulistiwa, Pendidikan Pancasila dan Kewarganegaraan, Sintang \\ Email: Suparnowae4@gmail.com, geri.88stg@gmail.com
}

\begin{abstract}
This article is motivated by the implementation of the 1945 Constitution of the Republic of Indonesia article 31 paragraph 1 through the eradication of the illiterate national program of empowering healthy and intelligent generation (PNPM-GSC) towards increasing public education awareness in the village of Tawang Sari, Sepauk District, Sintang Regency. The purpose of this study is to describe the implementation of the 1945 Constitution of the Republic of Indonesia article 31 paragraph 1 through the eradication of the illiterate national program of empowering healthy and intelligent generation (PNPM-GSC) towards increasing public education awareness in the village of Tawang Sari, Sepauk District, Sintang Regency. The method used in this study is a qualitative method with a descriptive research form. From the results of the research that has been carried out found several things, including the following: 1. the implementation of the 1945 Constitution of the Republic of Indonesia article 31 paragraph 1 through the eradication of the illiterate national program of empowering healthy and intelligent generation (PNPM-GSC) towards increasing public education awareness in the village of Tawang Sari went well. 2. Community education awareness in Tawang Sari Village, Sepauk District, Sintang Regency is still relatively low, this is indicated by the understanding of parents or the community that has not prioritized education. 3. The implementation of the 1945 Constitution of the Republic of Indonesia article 31 paragraph 1 through the eradication of the illiterate national program of empowering healthy and intelligent generation (PNPM-GSC) towards increasing public education awareness in the village of Tawang Sari, Sepauk District, Sintang Regency is in line with expectations, which can increase education awareness
\end{abstract}

Keywords: The 1945 Constitution of the Republic of Indonesia article 31 paragraph 1, PNPMGSC, Education. 


\begin{abstract}
ABSTRAK
Artikel ini dilatarbelakangi implementasi UUD NKRI 1945 pasal 31 ayat 1 melalui pengentasan buta aksara program nasional pemberdayaan masyarakat generasi sehat dan cerdas (PNPM-GSC) terhadap peningkatan kesadaran pendidikan masyarakat didesa tawang sari kecamatan sepauk kabupaten sintang. Tujuan dalam penelitian ini adalah untuk memaparkan implementasi UUD NKRI 1945 pasal 31 ayat 1 melalui pengentasan buta aksara program nasional pemberdayaan masyarakat generasi sehat dan cerdas (PNPM-GSC) terhadap peningkatan kesadaran pendidikan masyarakat didesa tawang sari kecamatan sepauk kabupaten sintang . Metode yang digunakan dalam penelitian ini adalah metode kualitatif dengan bentuk penelitian deskriptif. Dari hasil penelitian yang telah dilaksanakan ditemukan beberapa hal, antara lain sebagai berikut: 1 . Implementasi UUD NKRI 1945 Pasal 31 Ayat 1 Melalui Pengentasan Buta Akcara Program Nasional Pemberdayaan Masyarakat Generasi Sehat Dan Cerdas (PNPM-GSC) Di Desa Tawang Sari berlangsung dengan baik. 2. Kesadaran Pendidikan Masyarakat Di Desa Tawang Sari Kecamatan Sepauk Kabupaten Sintang masih tergolong rendah, hal ini ditandai dengan adanya pemahaman orang tua atau masyarakat belum mengutamakan untuk pendidikan. 3. Implementasi UUD NKRI 1945 Pasal 31 Ayat 1 Melalui Pengentasan Buta Akcara Program Nasional Pemberdayaan Masyarakat Generasi Sehat Dan Cerdas (PNPM-GSC) Terhadap Peningkatan Kesadaran Pendidikan Masyarakat di desa Tawang Sari Kecamatan Sepauk Kabupaten Sintang sesuai dengan harapan, yaitu dapat meningkatkan kesadaran berpendidikan.
\end{abstract}

Kata Kunci: UUD NKRI 1945 pasal 31 ayat 1, PNPM-GSC, Pendidikan. 


\section{A. Pendahuluan}

Buta aksara merupakan masalah utama yang dialami oleh hampir semua wilayah di Indonesia. Di Kalimantan Barat sendiri, Buta aksara merupakan masalah yang kompleks yang memerlukan penanganan dan program yang khusus dari masa ke masa, masalah Buta aksara bukan lagi sekedar masalah negara, akan tetapi menjadi masalah sosial yang menyangkut hampir semua aspek dalam interaksi sosial. Masalah Buta aksara menjadi salah satu faktor penyebab dari kompleksitas permasalahan negara. Kementrian Desa telah meluncurkan program untuk menurunkan angka Buta aksara dengan melalui Buta aksara (PNPM-GSC).

Sebagaimana diberitakan dalam Tribun Pontianak pada hari Minggu tanggal 28 Januari 2018 pukul 14:53 dengan judul "Miris! Ternyata 332 Ribu Warga Kalbar Buta Huruf, Datanya Tak Terbantahkan". Dinyatakan bahwa jumlah warga buta huruf di Kalbar pada 2017 mencapai 332.943 jiwa atau 6,75 persen dari total penduduk Kalbar yang mencapai 4.932.499 jiwa.Data ini sesuai data yang dirilis Badan Pusat Statistik (BPS) Kalbar berdasarkan hasil survei sosial ekonomi nasional.Angka 6,75 persen ini dari keseluruhan jumlah penduduk Kalbar yang berumur 15 tahun ke atas. Jika diranking berdasarkan kabupaten/kota, tingkat buta huruf tertinggi berada di
Kabupaten Kayong Utara mencapai 9,42 persen.

Terkhusus Kabupaten Sintang juga memiliki angka buta huruf yang besar yakni 35.772 jiwa atau 8,77 persen dari total jumlah penduduk yang mencapai 407.901 jiwa. Berdasarkan data terakhir yang dihimpun dan diterima Dinas Pendidikan dan Kebudayaan Kabupaten Sintang pada 2015-2016, masih ada sekitar 29.165 penduduk tuna aksara di Kabupaten Sintang. Jumlah tersebut terbagi menjadi 14.112 laki-laki dan 15.053 perempuan.

Pemerintah selaku pemegang kekuasaan tertinggi berkewajiban melaksanakan berbagai program dan stimulus untuk mengatasi masalah kemiskinan. Sebagaimana yang diamanahkan pada pembukaan UUD 1945 menyatakan bahwa "Pembukaan UUD 1945, yakni: Pemerintahan Negara Indonesia yang melindungi segenap bangsa Indonesia dan seluruh tumpah darah Indonesia dan untuk memajukan kesejahteraan umum, mencerdaskan kehidupan bangsa, dan ikut melaksanakan ketertiban dunia yang berdasarkan kemerdekaan, perdamaian abadi dan keadilan sosial. Selain itu Pasal 30 ayat (1) UUD 1945 yang berbunyi: ayat (1) tiap-tiap warga negara berhak mendapatkan pengajaran.

Pemerintah dalam menangani pemberantasan buta aksara melakukan strategi atau trobosan yakni melalui kementerian Desa yang berupa Program Nasional Pemberdayaan Masyarakat Gerakan Sehat dan Cerdas (PMPN GSC). 
Program Nasioanal Pemberdayaan Masyarakat-Gerakan Sehat dan Cerdas (PMPN-GSC) ialah Program Generasi Sehat dan Cerdas (GSC) merupakan salah satu progam pemerintah dalam rangka penanggulangan kemiskinan guna mendukung pencapaian target Sustainable Development Goals (SDG's) dibidang pendidikan dan kesehatan. GSC juga merupakan program khusus yang kegiatannya fokus pada penanggulangan masalah akses masyarakat terhadap layanan bidang kesehatan dan pendidikan, menggerakan dan menyadarkan masyarakat akan pentingnya kesehatan Ibu dan Anak, Pendidikan Dasar dan Menengah Pertama serta pendidikan Anak Usia Dini. Pemerintah Indonesia meluncurkan Program Nasional Pemberdayaan Masyarakat (PNPM) Generasi Sehat dan Cerdas (GSC) yang bertujuan menguji pemanfaatan sistem hibah dana dalam rangka mendukung Tujuan Pembangunan Milenium (Millennium Development Goals) bidang pendidikan dan kesehatan secara partisipatif. Program ini mendorong peningkatan layanan kesehatan bagi ibu hamil, pengurangan angka kematian ibu dan balita serta mendukung pendidikan dasar bagi anak usia sekolah.

Progam GSC memanfaatkan dana Bantuan Langsung Masyarakat yang memungkinkan masyarakat dan penyedia layanan kesehatan dan pendidikan setempat saling bekerjasama mengidentifikasi masalah-masalah mendesak dari sisi layanan kesehatan dan pendidikan. Tujuannya, mengembangkan solusi guna menjawab masalah sesuai kondisi setempat. Program GSC dimulai dari tahapan persiapan dan sosialisasi pengenalan kondisi desa guna penyusunan profil desa dalam bidang kesehatan dan pendidikan. Berikutnya, perencanaan partisipatif dengan pendampingan fasilitator guna mengidentifikasi masalah serta mengembangkan solusi kreatif sesuai kondisi setempat.

Strategi ke depan, program GSC akan melakukan integrasi perencanaan seiring dengan rencana implementasi UU Nomor 6 Tahun 2014 tentang Desa. Tujuannya, menempatkan segala kegiatan kesehatan dan pendidikan GSC ke dalam Rencana Kegiatan Pembangunan Desa serta Anggaran Pembangunan dan Belanja Desa.

Hal ini menyebabkan peneliti tertarik untuk mengkaji lebih mendalam lagi apakah efektif program bantuan sosial yang diberikan oleh pemerintah terutama bagi keluarga penerima manfaat memiliki kesadaran dalam berpendidikan. Dengan judul "Implementasi UUD NKRI 1945 Pasal 31 Ayat 1 Melalui Pengentasan Buta Aksara Program Nasional Pemberdayaan Masyarakat Generasi Sehat Dan Cerdas (PNPM-GSC) Terhadap Peningkatan Kesadaran Pendidikan Masyarakat Didesa Tawang Sari Kecamatan Sepauk Kabupaten Sintang”. 


\section{B. Metode}

Metode merupakan suatu strategi dalam membantu peneliti untuk mendapatkan suatu capaian yang diharapkan. Menurut Sugiyono (2015 : 2) "metode penelitian pada dasarnya merupakan cara ilmiah untuk mendapatkan data dengan tujuan dan kegunaan tertentu". Metode deskriptif kualitatif sebagaimana dikemukakan oleh Nawawi (2012: 67) "metode deskriptif dapat diartikan sebagai prosedur pemecahan masalah yang diselidiki dengan menggambarkan/ melukiskan keadaan subyek/obyek penelitian pada saat sekarang berdasarkan fakta-fakta yang tampak, atau sebagaimana adanya".

Subjek dalam penelitian ini adalah Keluarga Penerima Manfaat Program Nasioanal Pemberdayaan Masyarakat Sehat dan Cerdas.Objek pada penelitian ini adalah Keluarga Penerima Manfaat Program Nasioanal Pemberdayaan Masyarakat Sehat dan Cerdas di Desa Tawang Sari Kecamatan Sepauk Kabupaten Sintang KalimantanBarat.

Penentuan subjek dan objek penelitian purposive sampling atau sampel bertujuan. Jumlah sampel disesuaikan dengan kebutuhan penelitian. Subjek dipilih menggunakan teknik Snowbal Sampling atau sampel jenuh, dimana jumlah subjek penelitian cenderung bertambah berdasarkan keperluan. Kriteria penentuan subjek penelitian diantaranya: Keluarga Penerima Manfaat Program Nasioanal
Pemberdayaan Masyarakat Sehat dan Cerdasdi Desa Tawang Sari Kecamatan Sepauk Kabupaten Sintang Kalimantan Barat.

Teknik analisis data yang digunakan adalah teknik analisis data deskriptif kualitatif memanfaatkan persentase hanya merupakan langkah awal dari proses analisis data (Arikunto, 2000: 352). Dalam proses selanjutnya analisis data kualitatif terdiri dari empat alur kegiatan yang terjadi secara bersamaan, yaitu catatan lapangan, pengumpulan informasi, penyajian informasi, dan penarikan kesimpulan (Miles dan Huberman, 1992: 16-21). Proses analisis data dilakukan secara simultan yang mencakup klarifikasi, interpretasi dan analisis data.

\section{Pembahasan Dan Hasil}

Implementasi UUD NKRI 1945 Pasal 31 Ayat 1 Melalui Pengentasan Buta Akcara Program Nasional Pemberdayaan Masyarakat Generasi Sehat Dan Cerdas (PNPM-GSC) Di Desa Tawang Sari.

Upaya penanggulangan Buta Aksara di desa Tawang Sari yaitu melalui Dinas Pemerintahan Desa berupa suatu program bantuan kepada masyarakat. Adapun program tersebut berupa Program Nasional Pemberdayaan Masyarakat-Gerakan Sehat dan Cerdas (PMPN-GSC). Program Nasional Pemberdayaan Masyarakat-Gerakan Sehat dan Cerdas (PMPN-GSC) ialah Program Generasi Sehat dan Cerdas (GSC) 
merupakan salah satu progam pemerintah dalam rangka penanggulangan kemiskinan guna mendukung pencapaian target Sustainable Development Goals (SDG's) dibidang pendidikan dan kesehatan. GSC juga merupakan program khusus yang kegiatannya fokus pada penanggulangan masalah akses masyarakat terhadap layanan bidang kesehatan dan pendidikan, menggerakan dan menyadarkan masyarakat akan pentingnya kesehatan Ibu dan Anak, Pendidikan Dasar dan Menengah Pertama serta pendidikan Anak Usia Dini. Pemerintah Indonesia meluncurkan Program Nasional Pemberdayaan Masyarakat (PNPM) Generasi Sehat dan Cerdas (GSC) yang bertujuan menguji pemanfaatan sistem hibah dana dalam rangka mendukung Tujuan Pembangunan Milenium (Millennium Development Goals) bidang pendidikan dan kesehatan secara partisipatif. Program ini mendorong peningkatan layanan kesehatan bagi ibu hamil, pengurangan angka kematian ibu dan balita serta mendukung pendidikan dasar bagi anak usia sekolah.

Progam GSC memanfaatkan dana Bantuan Langsung Masyarakat yang memungkinkan masyarakat dan penyedia layanan kesehatan dan pendidikan setempat saling bekerjasama mengidentifikasi masalah-masalah mendesak dari sisi layanan kesehatan dan pendidikan. Tujuannya, mengembangkan solusi guna menjawab masalah sesuai kondisi setempat. Program GSC dimulai dari tahapan persiapan dan sosialisasi pengenalan kondisi desa guna penyusunan profil desa dalam bidang kesehatan dan pendidikan. Berikutnya, perencanaan partisipatif dengan pendampingan fasilitator guna mengidentifikasi masalah serta mengembangkan solusi kreatif sesuai kondisi setempat.

Strategi ke depan, program GSC akan melakukan integrasi perencanaan seiring dengan rencana implementasi UU Nomor 6 Tahun 2014 tentang Desa. Tujuannya, menempatkan segala kegiatan kesehatan dan pendidikan GSC ke dalam Rencana Kegiatan Pembangunan Desa serta Anggaran Pembangunan dan Belanja Desa.

Pengentasan buta aksara melalui porogram PNPM-GSC di desa Tawang Sari telah berjalan dengan baik. Program ini sesuai dengan dengan tujuan yang telah dilaksanakan, hal ini ditandai dengan adanya kegiatan yang dilakukan dilingkungan masyarakat. Program kerja yang dilakukan berupa: pertama PNPM-GSC memberikan bantuan biaya untuk sekolah bagi warga yang tidak mampu; kedua memberikan penguatan kepada masyarakat untuk selalu menyekolahkan anaknya sampai kejenjang perguruan tinggi; ketiga membina anak-anak generasi mudanya dengan memberikan motivasi dan dorongan untuk bersekolah. 
Kesadaran Pendidikan

Masyarakat Di Desa Tawang Sari Kecamatan Sepauk Kabupaten Sintang.

Kesadaran pendidikan di desa

Tawang Sari masih tergolong rendah, hal ini ditandai dengan adanya pemahaman orang tua atau masyarakat belum mengutamakan untuk pendidikan. Kendatinya bahwa keluarga adalah unit terkecil dari suatu masyarakat yang terdiri dari suami, isteri dan anak-anak, dan sekaligus merupakan lembaga yang kokoh sebagai lembaga pendidikan yang pertama dan utama bagi setiap insan manusia. Keluarga adalah unit terkecil dari masyarakat dan sekaligus sebagai lembaga pendidikan pertama dan utama mempunyai fungsi mendidik anak secara dini sampai dewasa. Pendidikan dalam keluarga tidak saja menyangkut masalah pengetahuan dan keterampilan tetapi juga menyangkut masalah etika, moralitas dan mental bagi anak, dari semua aspek kehidupan manusia sekarang ini.

Pendidikan anak tidak akan baik, perilakunya menjadi liar, tidak punya pandangan hidup yang mantap, sehingga ia akan menjadi ancaman bagi lingkungannya sendiri. Jelas sebagai orang tua mempunyai tanggung jawab terhadap: 1) Tuhan; 2) terhadap hati nurani sebagai sumber nilai-nilai luhur manusia; 3) Masyarakat. Oleh karena itu, tugas yang telah diembankan oleh setiap manusia sebagai makhluk Tuhan, perlu dilaksanakan dengan rasa tanggung jawab, karena tugas itu adalah tugas yang paling penting bagi pendidikan anak. Jika anak gagal dalam pertumbuhannya dan perkembangannya terhadap pendidikan anak (Zakiah, D. dkk,(1992:89).

Implementasi UUD NKRI 1945 Pasal 31 Ayat 1 Melalui Pengentasan Buta Akcara Program Nasional Pemberdayaan Masyarakat Generasi Sehat Dan Cerdas (PNPM-GSC) Terhadap Peningkatan Kesadaran

Pendidikan Masyarakat di desa Tawang Sari Kecamatan Sepauk Kabupaten Sintang.

Penerapan program PNPMGSC yang dilakukan di Desa Tawang Sari ini memberikan dampak positif terutama menjadikan masyarakat memiliki kesadaran berpendidikan. Kesadaran berpendidikan ini mendorong kepada anak-anaknya untuk bersekolah. Dengan demikian bahwa buta aksara di Desa Tawang Sari telah mengalami perbaikan. Sebagaimana sesuai dengan harapan dari program PNPM-GSC yakni PNPM GSC merupakan program fasilitasi masyarakat dalam rangka perencanaan dan pelaksanaan kegiatan peningkatan derajat kesehatan ibu dan anak, serta peningkatan akses pendidikan dasar dan menengah. Sebagai stimulan dalam menyusun perencanaan kegiatan yang akan dilakukan, program menyediakan Bantuan Langsung Masyarakat (BLM). Selain 
itu, perlu difasilitasi juga munculnya pendanaan dari sumber atau potensi yang ada dimasyarakat sendiri, pemerintah daerah atau dari kelompok peduli lainnya. Sejalan dengan Tujuan dari program ini adalah: a. Meningkatnya derajat kesehatan ibu dan anak-anak balita. b. Meningkatnya pendidikan anakanak usia sekolah hingga tamat Sekolah Dasar (SD.MI) dan Sekolah Lanjutan Tingkat Pertama (SMP/MTs); dan sasaran program ini adalah: 1. Seluruh ibu-ibu yang sedang hamil; 2. Ibu menyusui dan bayinya; 3. Anak-anak balita, serta 4. Anak-anak usia sekolah dasar dan menengah pertama

\section{Simpulan}

Berdasarkan hasil penelitian, dapat disimpulkan sebagai berikut:

1. Implementasi UUD NKRI 1945 Pasal 31 Ayat 1 Melalui Pengentasan Buta Aksara Program Nasional Pemberdayaan Masyarakat Generasi Sehat Dan Cerdas (PNPM-GSC) Di Desa Tawang Sari berlangsung dengan baik, dengan melakukan tiga program yakni: pertama PNPM-GSC memberikan bantuan biaya untuk sekolah bagi warga yang tidak mampu; kedua memberikan penguatan kepada masyarakat untuk selalu menyekolahkan anaknya sampai kejenjang perguruan tinggi; ketiga membina anak-anak generasi mudanya dengan memberikan motivasi dan dorongan untuk bersekolah.

2. Kesadaran Pendidikan Masyarakat Di Desa Tawang Sari Kecamatan
Sepauk Kabupaten Sintang masih tergolong rendah, hal ini ditandai dengan adanya pemahaman orang tua atau masyarakat belum mengutamakan untuk pendidikan.

3. Implementasi UUD NKRI 1945 Pasal 31 Ayat 1 Melalui Pengentasan Buta Aksara Program Nasional Pemberdayaan Masyarakat Generasi Sehat Dan Cerdas (PNPM-GSC) Terhadap Peningkatan Kesadaran Pendidikan Masyarakat di desa Tawang Sari Kecamatan Sepauk Kabupaten Sintang sesuai dengan harapan, yaitu dapat meningkatkan kesadaran berpendidikan.

\section{Daftar Pustaka}

Arikunto, Suharsimi. (2009). Prosedur Penelitian Suatu Pendekatan Praktik. Jakarta: Rineka Cipta.

Miles, Mattew B dan Hubermen, Michael. (1992). Analisa Data Kualitatif: Buku Sumber Tentang Metode Baru. Terjemahan Tjetjep Rohendy (2007), Jakarta: UI Press.

Nawawi, Hadari. (2012). Metode Penelitian Bidang Sosial. Yogyakarta: Gadjah Mada University Press.

Sugiyono. (2015). Metode Penelitian Kuantitatif Kualitatif dan $R \& D$. Bandung: Alfabeta.

Winarno. (2009). Pendidikan Kewarganegaraan. Jakarta: Bumi Aksara. 
Zakiah, D., dkk,(1992).There is nothing practikal thana goodtheory. Jakarta: Bumi Aksara.

Pembukaan Undang-Undang Dasar 1945.

Undang-Undang Dasar 1945 Pasal 31 Ayat 1.

Program Nasional Pemberdayaan Masyarakat Gerakan Sehat dan Cerdas (PNPM GSC). Tersedia di

https://www.scribd.com/doc/20 2451573/generasi-sehatcerdas-docx.

Tribun Pontianak. Minggu tanggal 28 Januari 2018 pukul 14:53. "Miris! Ternyata 332 Ribu Warga Kalbar Buta Huruf, Datanya Tak Terbantahkan”. 